\title{
Repetition in Surah al-Fath: (Qur'anic Stylistic Studies)
}

\author{
Hanik Mahliatussikah, Himatul Istiqomah \\ Universitas Negeri Malang, Indonesia \\ himastiq@gmail.com
}

\begin{abstract}
Language and literature have a complex relationship with religion. The concrete example of these relationship can be observed in the Qur'an. The Qur'an as a Muslim holy book is revealed in Arabic which is fulled by beautiful language styles. Even, the beauty of diction in the Qur'an was recognized by prominent Arabic literaturer in his time. One of language style which dominates the beauty of the Qur'an is repetition. Therefore, the research of repetition in the Qur'an is importance in term of linguistics, literature, and religion. Through a qualitative approach and content analysis, this research aims to explore the types of repetition in one of Madaniyah's surah, namely al-Fath. The results are found in this surah as follows. 1) There are four types of repetition in surah al-Fath, namely phonological, morphological, syntax, and semantic repetition. 2) The most common repetition found in Surah al-Fath is phonological repetition then syntax repetition. 3) Themost common type of phonological repetition is initial rhyme as morpheme. 4) the most common type of syntax repetition is word repetition as partial reduplication. The results of this research are useful as a theoretical reference, especially regarding the style of repetition in the Qur'an.
\end{abstract}

Keywords: Repetition, Qur'anic Stilistic, Al-Fath

\section{Introduction}

The Qur'an is the greatest miracle of the Prophet Muhammad. It is a masterpiece full of the beauty of language.Although it is not a literary work, the Qur'an descent shook the literary world with deeply shaken ${ }^{1}$. It even weakens the veteran Arabian literature One of them 2

${ }^{1}$ Agussalim Beddu Malla, 'Nilai Estetika Al - Qur' an Dan Pengaruhnya Terhadap Jiwa', Tamaddun: Jurnal Bahasa, Sastra, Dan Budaya, 17.1 (2018), 4-6 (p. 5).

${ }^{2}$ Mustafa Șādiq Al--Rāfi'i, I'jāz Al-Qur'ān Wa Al-Balāgat Al-Nabawiyah (Beirut: Dar al-Kitab al-Nabawi), pp. 17-18. 
was the famous Arab poet from Dousclan called Thufail. He became a Muslim after listening to several verses of the Qur'an red by the Prophet Muhammad ${ }^{3}$.

The Qur'an's postponement is capable of softening those who have a harsh personality .One of them was the second successor, Umar ibn alKhaththab. He became a Muslim after listening to several verses of the Qur'an read by his sister, Fatima binti al-Khaththab. ere was $\mathrm{Th}^{4}$ also Professor of Mathematics at Kansas University in the United States of America named Jeffrey Lang. He was an atheist then became a Muslim and created some Islamic books after studying the Qur'anhe Qur'an is 5 valid even withouttesting and proofing. Because the Qur'an contains a complete set of signified and the signifier. ${ }^{6}$

There is no doubt that the beauty of language has a more important role as part of the miracles of the Qur'an. It belongs to the Arabic language and literature from the Qur'anic stylistic studies that are taught about the use of beautiful language in the Qur'an7. The purpose of this study is to give decorations to the language, either spoken or written, where the reader or listener feels the specific effects ${ }^{8}$. It includes the phonological, morphological, syntax, and semantic that were issued from the Qur'an ${ }^{9}$. One of these studies is repetition. ${ }^{10}$

3 Abd al-Mālik Ibn Hisyām, Al-Sīrah Al-Nabawiyah Li Ibn Hisyām, II (Mesir: Mustafa al-Bābi al-Halabī wa awlādu, 1955), p. 383.

${ }^{4}$ Navid Kermani, 'The Aesthetic Reception of the Qur'an as Reflected in Early Muslim History', in Literary Structures of Religion Meaning in the Qur'an, ed. by Issa' J Boullata, I (Surrey: Curzon Press, 2000), p. 260.

${ }^{5}$ Ahmad Fuad Effendy, Sudahkah Kita Mengenal Al-Quran? (Malang: Misykat Indonesia, 2013), p. 5.

${ }^{6}$ Ibnu Khaldun, Muqaddimah Ibn Khaldun (Spanyol, 1377), p. 95.

${ }^{7}$ Syihabuddin Qalyubi, Stilistika Bahasa Dan Sastra Arab (Yogyakarta: Karya Media, 2013), p. 87.

${ }^{8}$ Gorys Keraf, Diksi Dan Gaya Bahasa (Jakarta: Gramedia-Pustaka Utama, 2007), p. 112; Nyoman Kutha Ratna, Stilistika: Kajian Puitika Bahasa, Sastra, Dan Budaya (Yogyakarta: Pustaka Pelajar, 2009), p. 8.

${ }^{9}$ Wahyu Hanafi, 'STILISTIKA AL-QUR'AN; (Ragam Gaya Bahasa Ayat-Ayat Talab Dalam Diskursus Stilistika) Wahyu', Al Mabsut:Jurnal Studi Islam Dan Sosial, 11.1 (2017), 1-19 (p. 1).

10 Tahereh Mirshahi and Ali Sabaghi, 'Repetition; the Stylistic Feature of Fakhr Al-Dīn Ibrahīm 'Irāqī’s Lyrics', Iran Journals, 13.54 (2017), 143-62 (p. 144). 
Repetition is the action of repeating something that has already been written or said. It has many functions in the structure of the sentence, such as destination confirmation 11. Repetition also has a function to highlight important things ${ }^{12}$. It was also useful as a request for addressing attention ${ }^{13}$.

Repetition is an important topic in common researchs, such as art, literature, and Qur'anic ${ }^{14}$. Some scholars saw that repetition in the Qur'an is a defect. However, other scholars saw that it was decorated ${ }^{15}$. Huda and Sa'dudin ${ }^{16}$ have also researched that repetition in Maulid Simt al-Duraar has an important function which is to give the greatest and strongest effect on readers and listeners.In the hadiths, Pransiska ${ }^{17}$ found that verbal repetition has functions to emphasize meaning, to warn, to

${ }^{11}$ Dwi Septiani, 'Majas Dan Citraan Dalam Puisi "Mishima” Karya Goenawan Mohamad (Kajian Stilistika)', Jurnal Sasindo Unpam, 8.1 (2020), 12-24 (p. 19); Erlina Zahar, 'Analisis Struktur Majas Seloko Hukum Adat Sebagai Bentuk Ekspresi Simbolik Nilai-Nilai Religius Masyarakat Melayu Jambi', Jurnal Ilmiah DIKDAYA, 8.1 (2018), 15059 (p. 157) <https://doi.org/10.33087/dikdaya.v8i1.96>; Hasmi Noviant, 'Penggunaan Majas Dalam Puisi Menggunakan Media Lagu Siswa Kelas VIII SMP Negeri I Gunung Talang', Jurnal Pendidikan Rokania, 2.2 (2017), 200-209 (p. 208) <https://doi.org/10.1017/CB09781107415324.004>.

12 Mohammad Makinuddin, 'Mengebal Ushlub Dalam Struktur Kalimat Dan Makna', MIYAH, Jurnal Studi Islam, 14.2 (2018), 160-81 (p. 170); Ogorodnikova L.A., Panin V.V., and Ryndina Yu.V, 'Stylistic Repetition In The Lyrics By Francis Albert Sinatra', Colloquium Journal, $8.60 \quad$ (2020), $80-82 \quad$ (p. 82) <https://doi.org/10.24411/2520-6990-2020-11547>.

13 Habeeb M. Areef Al-saeedi, 'The Function of Repetition in Trump ' s Inaugural Address: A Discourse Analysis Study', Education College Journal, 28.August 2017 (2018), 709-32 (p. 709).

14 Mo'taz Anad Ghozawan, 'جماليات التكرار في التصعيم الطباعي', Iraqi: Academic Scientific Journal, 15.14 (2017), 14-26 (p. 14).

15 Muhammad Luthfil Anshori, 'أسلوب التكرار في القرآن الكريم), Lisania: Journal of Arabic Education and Literature, 1.1 (2017), 56-73 (p. 56) <https://doi.org/10.18326/lisania.v1i1.56-73>.

16 'Stylistica of Maulid Simtud Durar's Repetition Created by Habib Ali Bin Muhammad Husein Al-Habsyi Nur', Jurnal Al Bayan: Jurnal Jurusan Pendidikan Bahasa Arab, 11.2 (2019), 232-53 (p. 232) <https://doi.org/10.24042/albayan.v>.

17 'أسلوب التكرار في الأحاديث النبوية (دراسة تطليبة دلالية) , Arabia: Jurnal Pendidikan Bahasa Arab, 10.1 (2018), 1-18 (p. 1). 
intimidate, or to threaten. It has been said that repetition as a sign of entrenchment, confirmation, alert, and affirmation. ${ }^{18}$

Al-Zarkasyi ${ }^{19}$ said that repetition is one of the values of miracles in the Qur'an. So, the research about it is important to do it. This is proven by the existence of previous scientific research on it. Nailah ${ }^{20}$ found in Surah al-Mursalat the use of repetition, including confirmation, determination, glorification, and conversion. Ihsanuddin ${ }^{21}$ found in Surah al-Syu'ara a different interpretation from the rule of repetition of $\mathrm{Al}$ Maraghi and Al-Shabuni. Maskhuroh ${ }^{22}$ found in Surah al-Rahman several interpretations of the repetition of the verses of Al-Mishbah, which are blessings, the resurrection, and the reward of deeds. Aisyah ${ }^{23}$ found in Surah al-An'am verbal and non-verbal repetition of affirmation, alertness, excitement, exaggeration in warning, and alienation. Najib and Arwan $^{24}$ found the use of repetition in phrase dlarranand naf'an, which puts a succession as a denial of polytheism. Nazri, Majid, and Abdullah 25 found the repetition of the word $m a a^{\prime}$ has the function as evidence of the miracle of the Qur'an in terms of eloquence. $M a a^{\prime}$ is the same word but it has different meanings.

Which has already been mentioned indicates the importance of the role of repetition in scientific research, especially in the Qur'anic studies.

18 Cholil Cholaf Basheer, 'التكرار والتناض في دعاء الندبة - دراسة دلالية, Iraqi: Academic Scientific Journal, 22.2 (2019), 423-46 (p. 426).

${ }^{19}$ Al-Burhān Fì Ulūmil Qur'ān (Kairo: Wahbah, 1991), p. 9.

20 'Penafsiran Ayat Tikrar Dalam Surah Al-Mursalat Menurut Muhammad 'Ali AlSabuni' (UIN Sunan Gunung Djati Bandung, 2018).

21 'Penerapan Kaidah Tikrar Dan Hikmahnya Dalam Surah Al-Shu'ara' Prespektif Ahmad Musthafa Al Maraghi Dan Muhammad Ali Al-Shabuni' (UIN Sunan Ampel Surabaya, 2016).

22 'Studi Pengulangan Ayat Pada Surat Al-Rahman (Telaah Atas Tafsir AlMisbah)', Jurnal Unisda, 2018, 70-84 (p. 83) <https://media.neliti.com/media/publications/265974-studi-pengulangan-ayat-padasurat-al-rah-485246dc.pdf>.

23 أسلوب التكرار في سورة الأنعام (UIN Sunan Ampel Surabaya, 2019).

24 'Ragam Makna Penafsiran Lafal Darran Dan Naf'an Secara Berdampingan (Kajian Pengulangan Al-Qur'an) Muhammad', ŚALIHAA, 3.1 (2020), 1-30 (p. 1).

25 'Repetition of Al-Ma' and Ma' in Quranic Context: Meanings and Intents', $\mathrm{Al}$ -

Turath Journal of Al-Quran and Al-Sunnah, 2.2 (2017), 80-87 (p. 80) <http://spaj.ukm.my/jalturath/index.php/jalturath/article/view/54>. 
Therefore, with qualitative descriptive approach, the researchers aim to continue the previous research by revealing the repetition style including phonological, morphological, syntax, and semantic in Surah al-Fath as one of surah Madaniyah in the Qur'an. This research will use to indicate a part of the eloquent miracle of the Qur'an. This also will give a contribution as a repetition theory, especially for Qur'anic stylistic studies.

\section{Types of Repetition}

Tarigan $^{26}$ said that repetition is the type of language style for repeating the word or a part ofthe word. Keraf ${ }^{27}$ said that repetition consists of eight types. That is also found in several previousresearch as follows ${ }^{28}$ :

1. Anaphora, the repetition occurs at the beginning of the sentences or verses.

2. Epiphora, the repetition occurs at the end of the sentences or verses.

3. Mesodiplosis, the repetition occurs in the modes of sentences or verses.

4. Tautotes, the repetition occurs repeatedly in the structure of sentences or verses.

5. Epizeuxis, the repetition occurs repeatedly in the sentences or verses.

6. Epanalepsys, the repetition of the first sentence in the final sentence or verse.

7. Anadiplosis, the repetition of the final sentence in the first sentence or verse.

8. Symploke, the repetition of the first and the final sentence in several sentences or verses.

${ }^{26}$ Pengajaran Kosa Kata (Bandung: Angkasa, 1993), p. 199.

${ }^{27}$ Diksi Dan Gaya Bahasa (Jakarta: Gramedia-Pustaka Utama, 2004).

${ }^{28}$ Alvyna Rohmatika, 'Repetisi Dalam Antologi Puisi Buku Latihan Tidur Karya Joko Pinurbo: Kajian Stilistika', Bapala, 5.2 (2018), 1-15 (p. 4); Sidiq Aji Pamungkas and Kundharu Saddono, 'Repetisi Dan Fungsinya Dalam Novel Di Tanah Lada Karya Ziggy Zezsyazeoviennazabrizkie: Analisis Stilistika', METASASTRA: Jurnal Penelitian Sastra, 11.1 (2018), 113-30 (p. 113) <https://doi.org/10.26610/metasastra.2018.v11i1.113130>; Mas Darul Ihsan, 'Repetition Values on Martin Luther King Jr. Speech', JEES Uournal of English Educators Society), 3.2 (2018), 177-88 (p. 177) <https://doi.org/10.21070/jees.v3i2.1236>; Dian Anik Cahyani and others, 'Repetition As Lexical Aspect of Autism Therapist in Speech Therapy Process', in Proceedings of the Fifth Prasasti International Seminar on Linguistics (Atlantis Press, 2019), CCCXXXVIII, 1015 (p. 101) <https://doi.org/10.2991/prasasti-19.2019.15>. 
Dineen mentioned that the repetition happens into the four elements of language, namely: phonological, morphological, syntax, and semantic ${ }^{29}$.Izzat and Ahmad 30 found in the poem Al-Syukru li Allah Syukran Laisa Yansharimthe phonological repetition included epicardial, spontaneous, and microscopic. Syahra and Baqee ${ }^{31}$ mentioned that repetition in applying has six types, namely: total repetition, partial, parallel, grammatical repetition, synonym, and semi-repetition.

\section{Phonological Repetition in Surah Al-Fath}

Phonological repetition is the variety of appearances affecting the vocal structure due to the joining of sounds in successive verses in which the particular phoneme ${ }^{32}$. Among the types of phonological repetition as follows. 1) Alliterationis the repetition of a consonant in successive words. 2) Assonance is the repetition of a vowel in successive words ${ }^{33} .3$ ) Initial rhyme, 4) middle rhyme, 5) final rhyme ${ }^{34}$.The final rhyme consists of three types. Firstly, terminal rhyme (saj' muththarraf) is the rhyme that occursbecause of the last word of consistent in qafiyah nor wazan. Secondly, parallel rhyme (saj' mutawazi) is the rhyme that occurs because of the last word of consistent in qafiyah and wazan. Thirdly, inlaid rhyme

${ }^{29}$ Mohd Imran Khan, 'Reduplication in Arabic and Urdu', International Journal of English and Education, 5.4 (2016), 336-44 (p. 337); Nurul Azizah and others, 'Repetisi Leksikal Pada Al-Quran Surat Al-Kafirun', in Prosiding Seminar Nasional Linguistiks Dan Sastra (SEMANTIK) (Semarang: UNS Press, 2019), pp. 656-62 (p. 658).

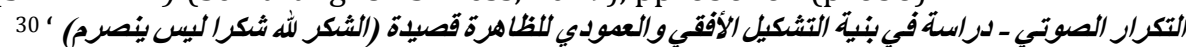

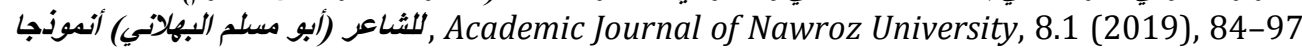
(p. 84) <https://doi.org/10.25007/ajnu.v8n1a310>.

31 'طاهرة التكرار في فن الدقامة ـ مقامة الوباء ـ لدحد الهويلحي ـ أندونجا (دراسة لسانية نصية) (Larbi Ben M'Hidi University, 2017).

32 Sarhan Gafat Salman and Royam Abdulhasan Majhul, ' التكرار في خطاب الاستكبار في (2018) القرآن الكريم (دراسة أسلوبية صوتية), Iraqi: Academic Scientific Journal, 18.4 (2018), 1-29 (p. 2).

${ }^{33}$ Riyadh Abbas Al-Jasy'ami, 'The Use of Phonological Repetition in the Texts of English Proverbs', Iraqi: Academic Scientific Journal, 20 (2009), 156-71 (p. 157); Alip Sugianto, 'Kajian Stilistika Terhadap Mantra Warok Etnik Jawa Panaragan', LEKSEMA: Jurnal Bahasa Dan Sastra, $1.2 \quad$ (2016), 81-88 (p. 88) <https://doi.org/10.22515/ljbs.v1i2.179>.

${ }^{34}$ Sri Wahyuni and Mohd Harun, 'Analisis Struktur Fisik Dan Struktur Batin Poisi Anak Dalam Majalah Potret Anak Cerdas', Master Bahasa, 6.2 (2018), 115-23 (p. 115). 
(saj' murashsha') is the rhyme that occurs because of the word is the same in qafiyah and wazan ${ }^{35}$.

\section{Alliteration}

Alliteration in Surah al-Fath is three types, as in the following table.

\begin{tabular}{|c|c|c|c|}
\hline No & Term & Verse & Type of repetition \\
\hline 1 & 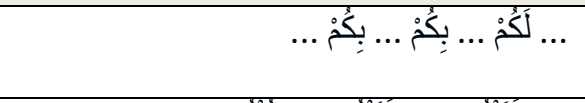 & 11 & $\begin{array}{l}\text { There is alliteration in } \\
\text { consonant "كم" }\end{array}$ \\
\hline 2 & 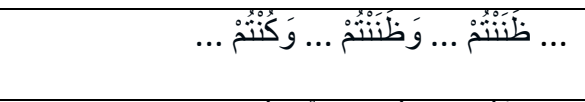 & 12 & $\begin{array}{l}\text { There is alliteration in } \\
\text { consonant "تم" }\end{array}$ \\
\hline 3 & 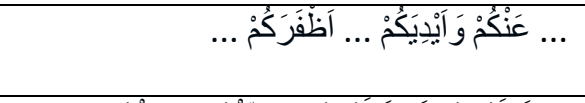 & 24 & $\begin{array}{l}\text { There is alliteration in } \\
\text { consonant "كم" }\end{array}$ \\
\hline 4 & 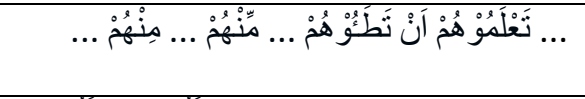 & 25 & $\begin{array}{l}\text { There is alliteration in } \\
\text { consonant "هم" }\end{array}$ \\
\hline 5 & 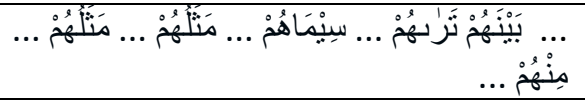 & 29 & $\begin{array}{l}\text { There is alliteration in } \\
\text { consonant "هم" }\end{array}$ \\
\hline
\end{tabular}

Table 1: Types of alliteration in Surah al-Fath

According to the previous table, alliteration was found in three consonants.The first, alliteration of "کُ" was found in two verses, in the

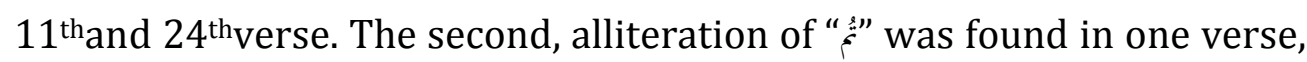
in the $12^{\text {th }}$ verse. The third, alliteration of " هُم" was found in two verses, in the $25^{\text {th }}$ and $29^{\text {th }}$ verse.

\section{Assonance}

Assonance in Surah al-Fath is seven types, as in the following table.

\begin{tabular}{|c|c|c|c|}
\hline No & Term & Verse & Type of repetition \\
\hline 1 & إِنَّا فَتَحَنَا ... مُّبِينًا & 1 & $\begin{array}{l}\text { There is assonance in } \\
\text { long vowel "نا" }\end{array}$ \\
\hline 2 & 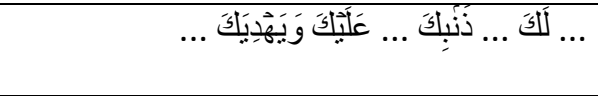 & 2 & $\begin{array}{l}\text { There is assonance in } \\
\text { short vowel “s"s" }\end{array}$ \\
\hline 3 & 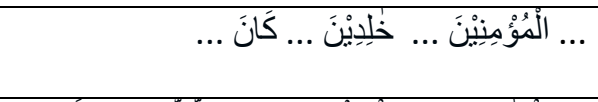 & 5 & $\begin{array}{l}\text { There is assonance in } \\
\text { short vowel "نَ" }\end{array}$ \\
\hline 4 & 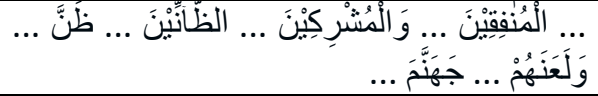 & 6 & $\begin{array}{l}\text { There is assonance in } \\
\text { short vowel "نَ" }\end{array}$ \\
\hline
\end{tabular}

35 A N M Nawas, M T Habeebullah, and A B M Aliyar, 'السجع في سورة القمر: دراسة تحليلية , in 6th International Symposium of FIA (Sri Lanka: South Eastern University of Sri Lanka, 2019), pp. 341-51 (p. 341). 


\begin{tabular}{|c|c|c|c|}
\hline No & Term & Verse & Type of repetition \\
\hline 5 & 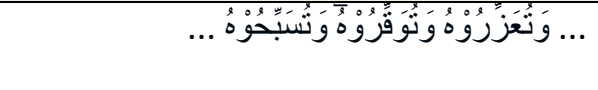 & 9 & $\begin{array}{l}\text { There is assonance in } \\
\text { short vowel "s" }\end{array}$ \\
\hline 6 & 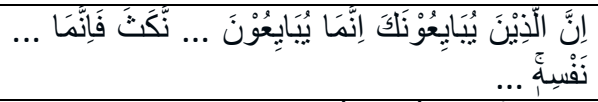 & 10 & $\begin{array}{l}\text { There is assonance in } \\
\text { short vowel "نَ" }\end{array}$ \\
\hline 7 & 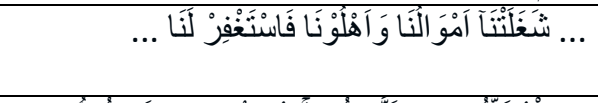 & 11 & $\begin{array}{l}\text { There is assonance in } \\
\text { long vowel "نا" }\end{array}$ \\
\hline 8 & 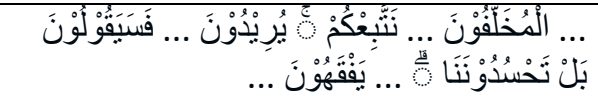 & 15 & $\begin{array}{l}\text { There is assonance in } \\
\text { short vowel "نَ" }\end{array}$ \\
\hline 9 & 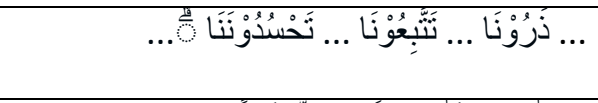 & 15 & $\begin{array}{l}\text { There is assonance in } \\
\text { long vowel "نا" }\end{array}$ \\
\hline 10 & 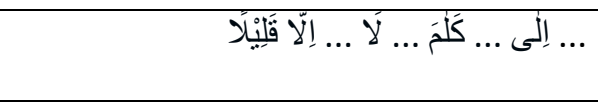 & 15 & $\begin{array}{l}\text { There is assonance in } \\
\text { long vowel "y" }\end{array}$ \\
\hline 11 & 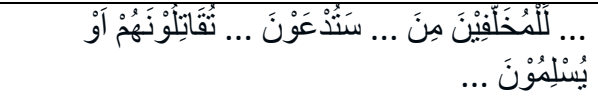 & 16 & $\begin{array}{l}\text { There is assonance in } \\
\text { short vowel "نَ" }\end{array}$ \\
\hline 12 & 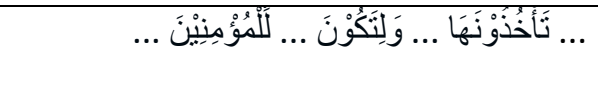 & 20 & $\begin{array}{l}\text { There is assonance in } \\
\text { short vowel "نَ" }\end{array}$ \\
\hline 13 & 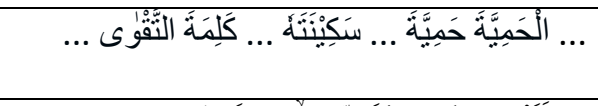 & 26 & $\begin{array}{l}\text { There is assonance in } \\
\text { short vowel "تَ" }\end{array}$ \\
\hline 14 & 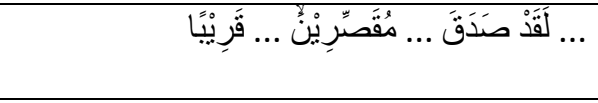 & 27 & $\begin{array}{l}\text { There is assonance in } \\
\text { short vowel "قَ" }\end{array}$ \\
\hline
\end{tabular}

Table 2: Types of alliteration in Surah al-Fath

According to the previous table, assonance was found in seven vowels. The first, assonance of "ن" was found in three verses, in the $1^{\text {st }}, 11^{\text {th }}$, and $15^{\text {th }}$ verse. The second, assonance of "كَ" was found in one verse, in the $2^{\text {nd }}$ verse. The third, assonance of "ن" was found in six verses, in the $5^{\text {th }}, 6^{\text {th }}, 10^{\text {th }}, 15^{\text {th }}, 16^{\text {th }}$, and $20^{\text {th }}$ verse. The fourth, assonance of "s" was found in one verse, in the $9^{\text {th }}$ verse. The fifth, assonance of " $y$ " was found in one verse, in the $15^{\text {th }}$ verse. The sixth, assonance of "ت" was found in one verse, in the $26^{\text {th }}$ verse. The seventh, assonance of " " was found in one verse, in the $27^{\text {th }}$ verse.

\section{Repetition of Initial Rhyme}

Repetition of initial rhyme in Surah al-Fath is two types, as in the following table. 


\begin{tabular}{|c|c|c|c|}
\hline No & Term & Verse & Type of repetition \\
\hline 1 & $\ldots \rho^{\varepsilon} \ldots \rho^{2}$ & 4 & $\begin{array}{l}\text { There is the repetition of initial rhyme } \\
\text { in morpheme form }\end{array}$ \\
\hline 2 & 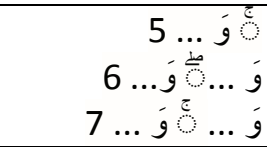 & $5,6,7$ & $\begin{array}{l}\text { There is the repetition of initial rhyme } \\
\text { in morpheme form }\end{array}$ \\
\hline 3 & 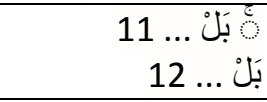 & 11,12 & $\begin{array}{l}\text { There is the repetition of initial rhyme } \\
\text { in morpheme form }\end{array}$ \\
\hline 4 & 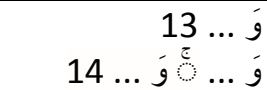 & 13,14 & $\begin{array}{l}\text { There is the repetition of initial rhyme } \\
\text { in morpheme form }\end{array}$ \\
\hline 5 & 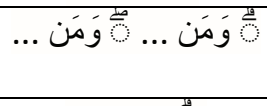 & 17 & $\begin{array}{l}\text { There is the repetition of initial rhyme } \\
\text { in word form }\end{array}$ \\
\hline 6 & 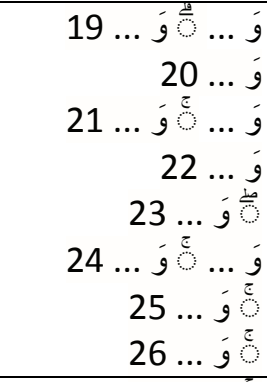 & $\begin{array}{l}19,20,21, \\
22,23,24, \\
25,26\end{array}$ & $\begin{array}{l}\text { There is the repetition of initial rhyme } \\
\text { in morpheme form }\end{array}$ \\
\hline 7 & 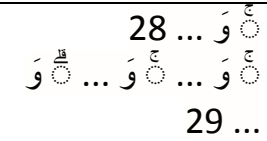 & 28,29 & $\begin{array}{l}\text { There is the repetition of initial rhyme } \\
\text { in morpheme form }\end{array}$ \\
\hline
\end{tabular}

Table 3: Types of repetition of initial rhyme in Surah al-Fath

According to the previous table, the repetition of the initial rhyme was found in two types, morpheme and word. The first, morpheme “" was found in 16 verses, in the $4^{\text {th }}, 5^{\text {th }}, 6^{\text {th }}, 7^{\text {th }}, 13^{\text {th }}, 14^{\text {th }}, 19^{\text {th }}, 20^{\text {th }}, 21^{\text {st }}, 22^{\text {nd }}$, $23^{\text {rd }}, 24^{\text {th }}, 25^{\text {th }}, 26^{\text {th }}, 28^{\text {th }}$, and 29th verse. While morpheme "بَّ" was found in two verses, in the $11^{\text {th }}$ and $12^{\text {th }}$ verse. The second, word “وَّمَ" was found in one verse, in the $17^{\text {th }}$ verse.

\section{Repetition of Middle Rhyme}

Repetition of middle rhyme in Surah al-Fath is three types, as in the following table.

\begin{tabular}{|c|c|l|l|}
\hline No & Term & Verse & \multicolumn{1}{c|}{ Type of repetition } \\
\hline 1 & $\ldots$ & 1,2 & $\begin{array}{l}\text { There is the repetition of middle rhyme in } \\
\text { phrase form }\end{array}$ \\
\hline 2 & $\ldots$ & $\ldots$ & $\ldots$ \\
\hline
\end{tabular}




\begin{tabular}{|c|c|c|c|}
\hline No & Term & erse & Type of re \\
\hline 3 & 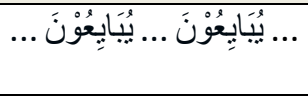 & 10 & $\begin{array}{l}\text { here is the repetition of middle rhyme in } \\
\text { ord form }\end{array}$ \\
\hline 4 & 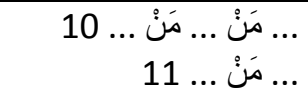 & 10,11 & $\begin{array}{l}\text { There is the repetition of middle rhyme in } \\
\text { word form }\end{array}$ \\
\hline 5 & .... فِيْ قَلْوب .... & 11,12 & $\begin{array}{l}\text { There is the repetition of middle rhyme in } \\
\text { phrase form }\end{array}$ \\
\hline 6 & 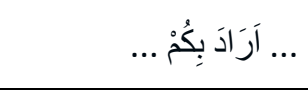 & 11 & $\begin{array}{l}\text { the repetition of middle rhyme in } \\
\text { orm }\end{array}$ \\
\hline 7 & ظَنَنْتُمْ ... & 12 & ne in \\
\hline 8 & 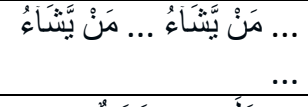 & 14 & ddle rhyme in \\
\hline 9 & 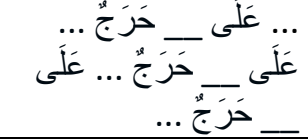 & 17 & middle rhyme in \\
\hline 10 & 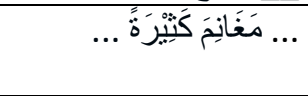 & 19,20 & $\begin{array}{l}\text { There is the repetition of } \\
\text { phrase form }\end{array}$ \\
\hline 11 & الْحَمِيَّةَة حَمِيَََّة ... & 26 & $\begin{array}{l}\text { There is the repetition of middle rhyme in } \\
\text { phrase form }\end{array}$ \\
\hline 12 & ينِ ... الدَِّّنِِِ ... & 28 & $\begin{array}{l}\text { There is the repetition of middle rhyme in } \\
\text { word form }\end{array}$ \\
\hline 13 & مَتَلَُهُمْ ... & 29 & $\begin{array}{l}\text { There is the repetition of } \\
\text { phrase form }\end{array}$ \\
\hline
\end{tabular}

Table 4: Types of repetition of middle rhyme in Surah al-Fath

According to the previous table, the repetition of the middle rhyme was found in three types.The first, phrase form was found in 10 verses, in the $1^{\text {st }}, 2^{\text {nd }}, 6^{\text {th }}, 11^{\text {th }}, 12^{\text {th }}, 14^{\text {th }}, 19^{\text {th }}, 20^{\text {th }}, 26^{\text {th }}$, and $2^{\text {th }}$ verse. The second, word form was found in 5 verses, in the $10^{\text {th }}, 11^{\text {th }}, 12^{\text {th }}, 17^{\text {th }}$, and $28^{\text {th }}$ verse. The third, morpheme form was found in one verse, in the $17^{\text {th }}$ verse.

\section{Repetition of Final Rhyme}

Repetition of final rhyme in Surah al-Fath is three types, as in the following table .

\begin{tabular}{|c|c|c|c|}
\hline No & Term & Verse & Type of repetition \\
\hline 1 & 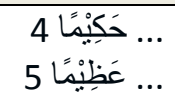 & 4,5 & $\begin{array}{l}\text { There is the repetition of final rhyme in } \\
\text { terminal rhyme (saj' muththarraf) }\end{array}$ \\
\hline 2 & $\begin{array}{c}11 . . . \\
12 \\
12 . . . .\end{array}$ & $\begin{array}{l}11,12 \\
13\end{array}$ & $\begin{array}{l}\text { There is the repetition of final rhyme in } \\
\text { terminal rhyme (saj' muththarraf) }\end{array}$ \\
\hline
\end{tabular}




\begin{tabular}{|c|c|c|c|}
\hline No & Term & Verse & Type of repetition \\
\hline & .... سَعِعْرِ 13 & & \\
\hline 3 & ... آلَِيًْا & 16,17 & $\begin{array}{l}\text { There is the repetition of final rhyme in inlaid } \\
\text { rhyme (saj' murashsha') }\end{array}$ \\
\hline 4 & 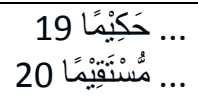 & 19,20 & $\begin{array}{l}\text { There is the repetition of final rhyme in } \\
\text { terminal rhyme (saj' muththarraf) }\end{array}$ \\
\hline 5 & 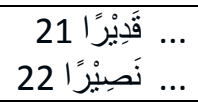 & 21,22 & $\begin{array}{l}\text { There is the repetition of final rhyme in } \\
\text { parallel rhyme (saj' mutawazi) }\end{array}$ \\
\hline 6 & 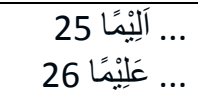 & 25,26 & $\begin{array}{l}\text { There is the repetition of final rhyme in } \\
\text { parallel rhyme (saj' mutawazi) }\end{array}$ \\
\hline
\end{tabular}

Table 5: Types of repetition of final rhyme in Surah al-Fath

According to the previous table, the repetition of the final rhyme was found in three types. The first, terminal rhyme (saj' muththarraf) was found in 7 verses, in the $4^{\text {th }}, 5^{\text {th }}, 11^{\text {th }}, 12^{\text {th }}$, and $13^{\text {th }}$ verse. The second, inlaid rhyme (saj' murashsha') was found in 2 verses, in the $16^{\text {th }}$ and $17^{\text {th }}$ verse. The third, parallel rhyme (saj' mutawazi) was found in 4 verses, in the $21^{\text {st }}, 22^{\text {nd }}, 25^{\text {th }}$, and $26^{\text {th }}$ verse.

\section{Morphological Repetition in Surah Al-Fath}

Morphological repetition occurs in morpheme, word, phrase, sentence, and speech, either partially or totally ${ }^{36}$. It leads to acoustic repetition, especially the repetitionof rhyme. It is also found in syntax structures and syntax sentences ${ }^{37}$.Therefore, the researcher grouped it into the following type of syntax repetition.

\section{Syntax Repetition in Surah Al-Fath}

Syntax repetition occurs in the internal structure of a language. There are four types of syntax repetition. The first is word repetition. The second is phrase repetition, which emphasizes the

${ }^{36}$ J.W.M. Verhaar, Pengantar Linguistik (Yogyakarta: UGM Press, 1992), p. 152.

37 Barbara Johnstone, Repetition in Arabic Discourse Paradigms, Syntagms, and the Ecology of Language (Amsterdam: John Benjamins Publishing, 1991), p. 56 <http://ncl.eblib.com/patron/FullRecord.aspx?p=740285>. 
development or change using contrast in the words following the similar 38. The third is clause repetition. The fourth is sentence repetition ${ }^{39}$.

\section{Word Repetition}

Repetition of the word in Surah al-Fath is four types, as in the following table.

\begin{tabular}{|c|c|c|c|}
\hline No & Term & Verse & Type of repetition \\
\hline 1 & 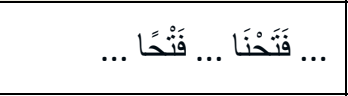 & 1 & $\begin{array}{l}\text { There is word repetition } \\
\text { asmesodiplosis in partial reduplication }\end{array}$ \\
\hline 2 & 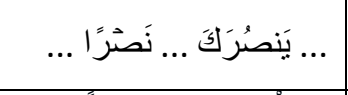 & 2 & $\begin{array}{l}\text { There is word repetition as } \\
\text { mesodiplosis in partial reduplication }\end{array}$ \\
\hline 3 & 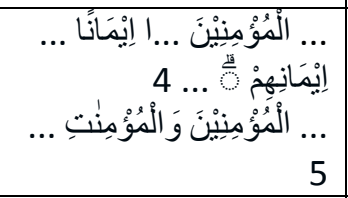 & 4,5 & $\begin{array}{l}\text { There is word repetition as tautotes in } \\
\text { partial reduplication }\end{array}$ \\
\hline 4 & ..... & 6 & $\begin{array}{l}\text { There is word repetition as } \\
\text { mesodiplosis in partial reduplication }\end{array}$ \\
\hline 5 & 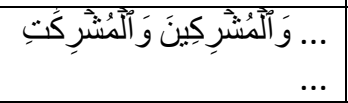 & 6 & $\begin{array}{l}\text { There is word repetition as } \\
\text { mesodiplosis in partial reduplication }\end{array}$ \\
\hline 6 & آلَظَّأَنِّنَ ... ظَنَّ ... & 6 & $\begin{array}{l}\text { There is word repetition as } \\
\text { mesodiplosis in partial reduplication }\end{array}$ \\
\hline 7 & 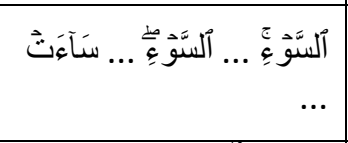 & 6 & $\begin{array}{l}\text { There is word repetition as tautotes in } \\
\text { total reduplication then partial } \\
\text { reduplication }\end{array}$ \\
\hline 8 & 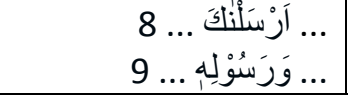 & 8,9 & $\begin{array}{l}\text { There is word repetition as } \\
\text { mesodiplosis in partial reduplication }\end{array}$ \\
\hline 9 & .... & 10 & $\begin{array}{l}\text { There is word repetition as } \\
\text { mesodiplosis in partial reduplication }\end{array}$ \\
\hline 10 & . & 10 & $\begin{array}{l}\text { There is word repetition as } \\
\text { mesodiplosis in partial reduplication }\end{array}$ \\
\hline 11 & |... & 11 & $\begin{array}{l}\text { There is word repetition as tautotes in } \\
\text { partial reduplication }\end{array}$ \\
\hline
\end{tabular}

38 Krystyna Mazur, Poetry and Repetition (Walt Whitman, Wallace Stevens, John Ashbery), ed. by William E. Cain (New York: Routledge Taylor \& Francis Group, 2005), p. 1.

${ }^{39}$ Mayada Hussein Rashid Azzawi Al-Jubouri, "The Phenomenon of Repetition in Mahiar Al-Daylami's Poetry (ظاهرة النكرار في شعر معيار الديلمي)', Journal of Tikrit University for the Humanities, 26.9 (2019), 220-36 (p. 220); Fatimah Safira, ' جمالية التكرار ودلالته في سورة الرحن (Mohamed Boudiaf University of M`Sila, 2017). 


\begin{tabular}{|c|c|c|c|}
\hline No & Term & Verse & Type of repetition \\
\hline 12 & 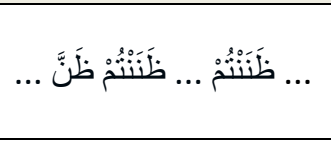 & 12 & $\begin{array}{l}\text { There is word repetition as tautotes in } \\
\text { total reduplication then partial } \\
\text { reduplication }\end{array}$ \\
\hline 13 & ... يَغْفِرُ ... غَفْورَ ... . . & 14 & $\begin{array}{l}\text { There is word repetition as } \\
\text { mesodiplosis in partial reduplication }\end{array}$ \\
\hline 14 & سَيَقُوْنُ ... فَسَيَقُقُ لُونَنَ ... & 15 & $\begin{array}{l}\text { There is word repetition as } \\
\text { mesodiplosis in partial reduplication }\end{array}$ \\
\hline 15 & 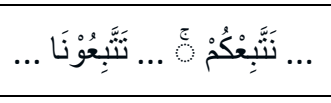 & 15 & $\begin{array}{l}\text { There is word repetition as } \\
\text { mesodiplosis in partial reduplication }\end{array}$ \\
\hline 16 & ... تَتَوَلَّوْ اكَمَا نَوَلَّنَّنُمْ ... & 16 & $\begin{array}{l}\text { There is word repetition as } \\
\text { mesodiplosis in partial reduplication }\end{array}$ \\
\hline 17 & 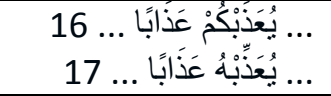 & 16,17 & $\begin{array}{l}\text { There is word repetition as } \\
\text { mesodiplosis in total reduplication }\end{array}$ \\
\hline 18 & 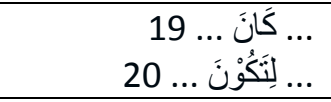 & 19,20 & $\begin{array}{l}\text { There is word repetition as } \\
\text { mesodiplosis in partial reduplication }\end{array}$ \\
\hline 19 & 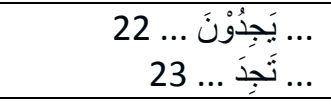 & 22,23 & $\begin{array}{l}\text { There is word repetition as } \\
\text { mesodiplosis in partial reduplication }\end{array}$ \\
\hline 20 & 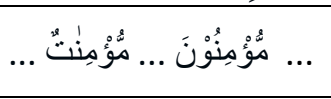 & 25 & $\begin{array}{l}\text { There is word repetition as } \\
\text { mesodiplosis in partial reduplication }\end{array}$ \\
\hline 21 & ... لَعَذَّبْنَا ... عَذَابًا .... & 25 & $\begin{array}{l}\text { There is word repetition as } \\
\text { mesodiplosis in partial reduplication }\end{array}$ \\
\hline 22 & . ... كَانُوْ ا... كَانَ ... & 26 & $\begin{array}{l}\text { There is word repetition as } \\
\text { mesodiplosis in partial reduplication }\end{array}$ \\
\hline 23 & ... فَعَلِحَ ... تَعْلَكَوْ ا.... & 27 & $\begin{array}{l}\text { There is word repetition as } \\
\text { mesodiplosis in partial reduplication }\end{array}$ \\
\hline 24 & ... اََرْسَلَ رَسُوْلَهُ ... & 27,28 & $\begin{array}{l}\text { There is word repetition as } \\
\text { mesodiplosis in partial reduplication }\end{array}$ \\
\hline 25 & ... الْكُفَّارِ ... الْكُفَّارَ ... & 29 & $\begin{array}{l}\text { There is word repetition as } \\
\text { mesodiplosis in total reduplication }\end{array}$ \\
\hline 26 & .... زَرْعٍع... الزُرَّاعَ.... & 29 & $\begin{array}{l}\text { There is word repetition as } \\
\text { mesodiplosis in partial reduplication }\end{array}$ \\
\hline
\end{tabular}

Table 6: Types of repetition of the word in Surah al-Fath

According to the previous table, the repetition of the word was found in two types. The first, mesodiplosis was found in 19 verses, in the $1^{\text {st }}, 2^{\text {nd }}, 6^{\text {th }}, 8^{\text {th }}, 9^{\text {th }}, 10^{\text {th }}, 14^{\text {th }}, 15^{\text {th }}, 16^{\text {th }}, 17^{\text {th }}, 19^{\text {th }}, 20^{\text {th }}, 22^{\text {nd }}, 23^{\text {rd }}, 25^{\text {th }}, 26^{\text {th }}$, $27^{\text {th }}, 28^{\text {th }}$, and $29^{\text {th }}$ verse. The second, tautotes was found in two verses, in the $11^{\text {th }}$ and $12^{\text {th }}$ verse. Besides that, there were also found two other typesof word repetition. The first is partial reduplication that was found in 22 verses, in the $1^{\text {st }}, 2^{\text {nd }}, 4^{\text {th }}, 5^{\text {th }}, 6^{\text {th }}, 8^{\text {th }}, 9^{\text {th }}, 10^{\text {th }}, 11^{\text {th }}, 12^{\text {th }}, 14^{\text {th }}, 15^{\text {th }}$, $16^{\text {th }}, 19^{\text {th }}, 20^{\text {th }}, 22^{\text {nd }}, 23^{\text {rd }}, 25^{\text {th }}, 26^{\text {th }}, 27^{\text {th }}, 28^{\text {th }}$, and $29^{\text {th }}$ verse. The second 
is total reduplication that was found in 4 verses, in the $6^{\text {th }}, 12^{\text {th }}, 16^{\text {th }}$, and $17^{\text {th }}$ verse.

\section{Phrase Repetition}

Repetition of the phrase in Surah al-Fath is three types, as in the following table.

\begin{tabular}{|c|c|c|c|}
\hline No & Term & Verse & Type of repetition \\
\hline 1 & 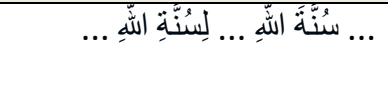 & 23 & $\begin{array}{l}\text { There is phrase repetition as } \\
\text { mesodiplosis in the nominal phrase }\end{array}$ \\
\hline 2 & 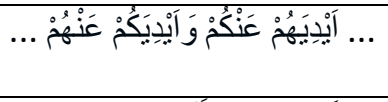 & 24 & $\begin{array}{l}\text { There is phrase repetition as } \\
\text { mesodiplosis in the nominal phrase }\end{array}$ \\
\hline 3 & ... اَرْسَلَ رَسُوْولَهُ ... & $\begin{array}{l}27, \\
28\end{array}$ & $\begin{array}{l}\text { There is phrase repetition as } \\
\text { mesodiplosis in the verbal phrase }\end{array}$ \\
\hline 4 & 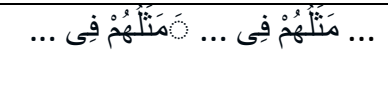 & 29 & $\begin{array}{l}\text { There is phrase repetition as } \\
\text { mesodiplosis in the nominal phrase }\end{array}$ \\
\hline
\end{tabular}

Table 7: Types of repetition of the phrase in Surah al-Fath

According to the previous table, the repetition of the phrase was found in one type. It was mesodiplosis that was found in 5 verses, in the $23^{\text {rd }}, 24^{\text {th }}, 27^{\text {th }}, 28^{\text {th }}$, and $2^{\text {th }}$ verse. Besides that, there were also found two other types of phrase repetition. The first is the nominal phrase that was found in three verses, in the $23^{\text {rd }}, 24^{\text {th }}$, and $29^{\text {th }}$ verse. The second is the verbal phrase that was found in two verses, in the $27^{\text {th }}$ and $28^{\text {th }}$ verse.

\section{Clause Repetition}

Repetition of the clause in Surah al-Fath is three types, as in the following table.

\begin{tabular}{|c|c|c|c|}
\hline No & Term & Verse & Type of repetition \\
\hline 1 & ... آرَادَ بِكُمْ ... آرَادَ بِكُمْ .... & 11 & $\begin{array}{l}\text { There is clause repetition as } \\
\text { mesodiplosis in the verbal clause }\end{array}$ \\
\hline 2 & 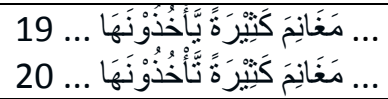 & $\begin{array}{l}19, \\
20\end{array}$ & $\begin{array}{l}\text { There is clause repetition as } \\
\text { mesodiplosis in the nominal clause }\end{array}$ \\
\hline
\end{tabular}

Table 8: Types of repetition of the clause in Surah al-Fath

According to the previous table, the repetition of the clause was found in one type. It was mesodiplosis that was found in three verses, in the $11^{\text {th }}, 19^{\text {th }}$, and $20^{\text {th }}$ verse. Besides that, there were also found two other types of clause repetition. The first is the verbal clause that was found in 
one verse, in the $11^{\text {th }}$ verse. The second is the nominal clause that was found in two verses, in the $19^{\text {th }}$ and $20^{\text {th }}$ verse.

\section{Sentence Repetition}

Repetition of the sentence in Surah al-Fath is three types, as in the following table.

\begin{tabular}{|c|c|c|c|}
\hline No & Term & Verse & Type of repetition \\
\hline 1 & 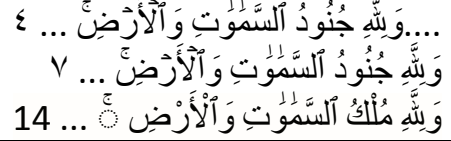 & 4,7 & $\begin{array}{l}\text { There is sentence repetition as } \\
\text { symploke in nominalsentence }\end{array}$ \\
\hline 2 & 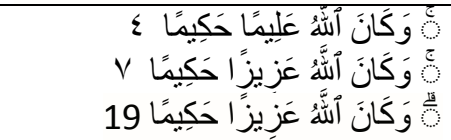 & $\begin{array}{l}4,7 \\
19\end{array}$ & $\begin{array}{l}\text { There is sentence repetition as } \\
\text { symploke in nominal sentence }\end{array}$ \\
\hline 3 & 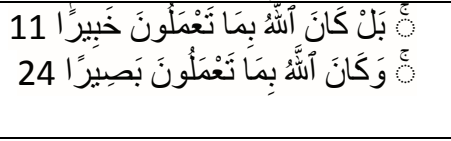 & 11,24 & $\begin{array}{l}\text { There is sentence repetition as } \\
\text { mesodiplosis in nominal } \\
\text { sentence }\end{array}$ \\
\hline
\end{tabular}

Table 9: Types of repetition of the sentence in Surah al-Fath

According to the previous table, the repetition of the sentence was found in two types. The first,symploke was found in five verses, in the $4^{\text {th }}$, $7^{\text {th }}$, and 19th verse. The second, mesodiplosis was found in two verses, in the $11^{\text {th }}$ and $24^{\text {th }}$ verse. Besides that, there was also found one other type of sentence repetition, namely the nominal sentence. It was repeated in five verses, in the $4^{\text {th }}, 7^{\text {th }}, 11^{\text {th }}, 19^{\text {th }}$, and $24^{\text {th }}$ verse.

\section{Semantic Repetition in Surah Al-Fath}

Semantic repetition focuses on the correlation of meaning between one sentence and the other ${ }^{40}$. Semantic repetition can be found in different terms, but they have similar meanings ${ }^{41}$. Among its type that was found in Surah Al-Fath is the repetition of the theme.

\section{Theme Repetition}

${ }^{40}$ Siti Sukriyah, Sumarlam Sumarlam, and Djatmika Djatmika, 'Lexical Cohesion of Synonyms, Antonyms, and Repetitions on the Rubric of Children's, Adolescent's, and Adults' Story in the Daily Newspaper Kompas', Aksara, 30.2 (2018), 267-84 (p. 270) <https://doi.org/10.29255/aksara.v30i2.230.267-283>.

${ }^{41}$ Wahyu Widodo, Mantra Kidung Jawa: Mengurai Yang Lingual Hingga Yang Transendental (Malang: UB Press, 2018), p. 56. 
Repetition of the theme in Surah Al-Fath is one type, as in the following table .

\begin{tabular}{|c|c|c|c|}
\hline No & Term & Verse & Type of repetition \\
\hline 1 & 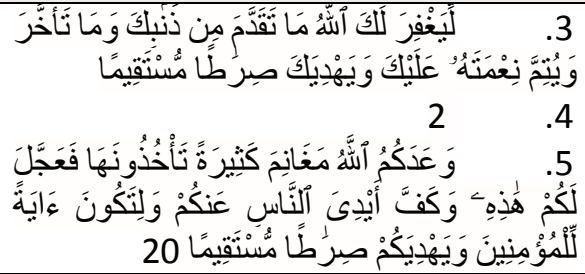 & 2,20 & $\begin{array}{l}\text { There is theme } \\
\text { repetition as epiphora } \\
\text { about the straight path } \\
\text { as a clue from God }\end{array}$ \\
\hline 2 & 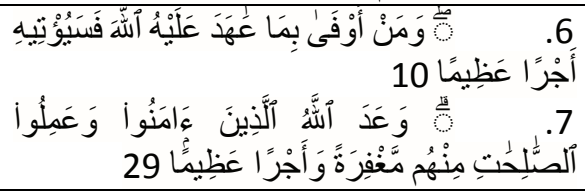 & 10,29 & $\begin{array}{l}\text { There is theme } \\
\text { repetition as epiphora } \\
\text { about the great reward } \\
\text { as a promise from God }\end{array}$ \\
\hline 3 & 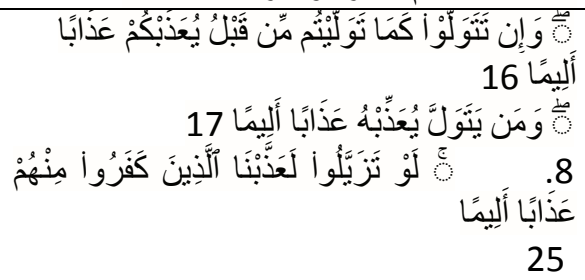 & $\begin{array}{l}16,17, \\
25\end{array}$ & $\begin{array}{l}\text { There is theme } \\
\text { repetition as epiphora } \\
\text { about the painful } \\
\text { punishment as a threat } \\
\text { from God }\end{array}$ \\
\hline
\end{tabular}

Table 10: Types of repetition of the theme in Surah al-Fath

According to the previous table, the repetition of the theme was found in one type, namely epiphora. The first theme repetition is about the straight path as a clue from God that was found in the $2^{\text {nd }}$ and $20^{\text {th }}$ verse. The second theme repetition is about the great reward as a promise from God that was found in the $10^{\text {th }}$ and $29^{\text {th }}$ verse. The third theme repetition is about the painful punishment as a threat from God that was found in the $16^{\text {th }}, 17^{\text {th }}$, and $25^{\text {th }}$ verse.

\section{Conclusion}

As previously discussed, the researchers could conclude the results of this research into four parts. Firstly, phonological repetition in Surah al-Fath was found in five types, namely alliteration, assonance, initial rhyme, middle rhyme, and final rhyme. Alliteration was found in three types. Alliteration in consonant " " was repeated in two verses. Alliteration in consonant " $\vec{F}$ " was repeated in one verse. Alliteration in consonant "هم" was repeated in two verses. Assonance was found in seven types. Assonance in long vowel "ن" was repeated in three verses. 
Assonance in short vowel "كَ" was repeated in one verse. Assonance in short vowel “" was repeated in six verses. Assonance in short vowel "s" was repeated in one verse. Assonance in long vowel " $y$ " was repeated in one verse. Assonance in short vowel “" " was repeated in one verse. Assonance in short vowel “قَ" was repeated in one verse.

The repetition of the initial rhyme was found in two types. Initial rhyme as morpheme was repeated in eighteen verses. Initial rhyme as the word was repeated in one verse. The repetition of the middle rhyme was found in three types. Middle rhyme as the phrase was repeated in ten verses. Middle rhyme as the word was repeated in five verses. Middle rhyme as morpheme was repeated in one verse.The repetition of the final rhyme was found in three types. The final rhyme as a terminal rhyme was repeated in seven verses. Final rhyme as inlaid rhyme was repeated in two verses. The final rhyme as a parallel rhyme was repeated in four verses.

Secondly, morphological repetition in Surah al-Fath was included in syntax repetition. Because both of them are similar. Thirdly, syntax repetition in Surah al-Fath was found in five types, namely word repetition, phrase repetition, clause repetition, and sentence repetition. Word repetition was found in four types. Mesodiplosis was found in five verses. Tautotes was found in twoverses. Partial reduplication was found in 22 verses. Total reduplication was found in four verses. Phrase repetition was found in three types. Mesodiplosis was found in five verses. Nominal phrase was found in three verses. Verbal phrase was found in two verses. Clause repetition was found in three types. Mesodiplosis was found in three verses. Verbal clause was found in one verse. Nominal clause was found in two verses. Sentence repetition was found in three types. Symploke was found in three verses. Mesodiplosis was found in two verses. Nominal sentence was repeated in five verses. Fourthly, semantic repetition in Surah al-Fath was found in one type, namely theme repetition. It was also found in one type, namely epiphora. It was found in seven verses with three themes. 
According to the conclusion above, it can be said that the most common repetition found in Surah al-Fath is phonological repetition then syntax repetition. Whereas the most common type of phonological repetition is initial rhyme as morpheme. While the most common type of syntax repetition is word repetition as partial reduplication.

\section{Acknowledgement}

This research was supported by PNBP Universitas Negeri Malang. We thank our collegues from Universitas Negeri Malang who provided insight and expertise that greatly assisted the research, although they may not agree with all of the interpretations/conclusions of this article.

\section{References}

Aisyah, Siti, 'أسلوب التكرار في سورة الأنعام' (UIN Sunan Ampel Surabaya, 2019)

Al-Jasy'ami, Riyadh Abbas, 'The Use of Phonological Repetition in the Texts of English Proverbs', Iraqi: Academic Scientific Journal, 20 (2009), 156-71

Al-Jubouri, Mayada Hussein Rashid Azzawi, 'The Phenomenon of

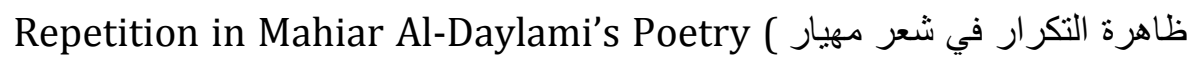
(الديلمي', Journal of Tikrit University for the Humanities, 26.9 (2019), 220-36

Al--Rāfi'i, Mustafa Șādiq, I'jāz Al-Qur'ān Wa Al-Balāgat Al-Nabawiyah (Beirut: Dar al-Kitab al-Nabawi)

Al-saeedi, Habeeb M. Areef, 'The Function of Repetition in Trump ' s Inaugural Address: A Discourse Analysis Study', Education College Journal, 28.August 2017 (2018), 709-32

Anshori, Muhammad Luthfil, 'أسلوب التكر ار في القرآن الكريم', Lisania: Journal of Arabic Education and Literature, 1.1 (2017), 56-73 <https://doi.org/10.18326/lisania.v1i1.56-73>

Az-Zarkasyi, Burhānuddin, Al-Burhān Fī Ulūmil Qur'ān (Kairo: Wahbah, 1991)

Azizah, Nurul, Putri Palupi, Ilfia Rahmi Rasyid, and Nur Hizbullah, 'Repetisi Leksikal Pada Al-Quran Surat Al-Kafirun', in Prosiding Seminar Nasional Linguistiks Dan Sastra (SEMANTIK) (Semarang: 
UNS Press, 2019), pp. 656-62

Basheer, Cholil Cholaf, 'التكرار و التناض في دعاء الندبة ـ دراسة دلالية', Iraqi: Academic Scientific Journal, 22.2 (2019), 423-46

Cahyani, Dian Anik, Sumarlam, Djatmika, and Dwi Purnanto, 'Repetition As Lexical Aspect of Autism Therapist in Speech Therapy Process', in Proceedings of the Fifth Prasasti International Seminar on Linguistics (Atlantis Press, 2019), CCCXXXVIII, 101-5 <https://doi.org/10.2991/prasasti-19.2019.15>

Effendy, Ahmad Fuad, Sudahkah Kita Mengenal Al-Quran? (Malang: Misykat Indonesia, 2013)

Ghozawan, Mo'taz Anad, 'جماليات التكرار في التصميم الطباعي', Iraqi: Academic Scientific Journal, 15.14 (2017), 14-26

Hisyām, Abd al-Mālik Ibn, Al-Sīrah Al-Nabawiyah Li Ibn Hisyām, II (Mesir: Mustafa al-Bābi al-Halabī wa awlādu, 1955)

Huda, Nur, and Ihsan Sa'dudin, 'Stylistica of Maulid Simtud Durar's Repetition Created by Habib Ali Bin Muhammad Husein Al-Habsyi Nur', Jurnal Al Bayan: Jurnal Jurusan Pendidikan Bahasa Arab, 11.2 (2019), 232-53 <https://doi.org/10.24042/albayan.v>

Ihsan, Mas Darul, 'Repetition Values on Martin Luther King Jr. Speech', JEES (Journal of English Educators Society), 3.2 (2018), 177-88 $<$ https://doi.org/10.21070/jees.v3i2.1236>

Ihsanuddin, 'Penerapan Kaidah Tikrar Dan Hikmahnya Dalam Surah AlShu'ara' Prespektif Ahmad Musthafa Al Maraghi Dan Muhammad Ali Al-Shabuni' (UIN Sunan Ampel Surabaya, 2016)

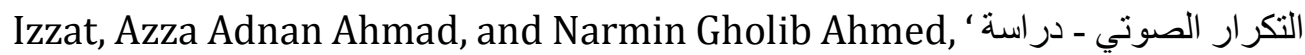

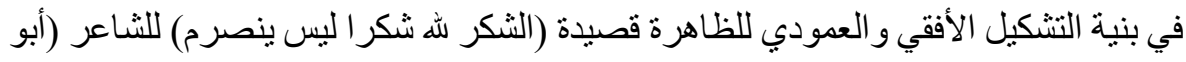

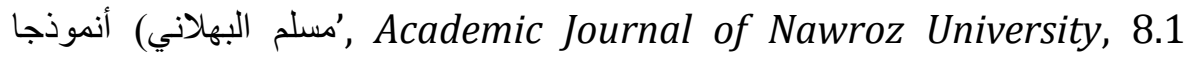
(2019), 84-97 <https://doi.org/10.25007/ajnu.v8n1a310>

Johnstone, Barbara, Repetition in Arabic Discourse Paradigms, Syntagms, and the Ecology of Language (Amsterdam: John Benjamins Publishing, 1991) <http://ncl.eblib.com/patron/FullRecord.aspx?p=740285> 
Keraf, Gorys, Diksi Dan Gaya Bahasa (Jakarta: Gramedia-Pustaka Utama, 2007)

__—, Diksi Dan Gaya Bahasa (Jakarta: Gramedia-Pustaka Utama, 2004)

Kermani, Navid, 'The Aesthetic Reception of the Qur'an as Reflected in Early Muslim History', in Literary Structures of Religion Meaning in the Qur'an, ed. by Issa' J Boullata, I (Surrey: Curzon Press, 2000)

Khaldun, Ibnu, Muqaddimah Ibn Khaldun, (Spanyol, 1377)

Khan, Mohd Imran, 'Reduplication in Arabic and Urdu', International Journal of English and Education, 5.4 (2016), 336-44

L.A., Ogorodnikova, Panin V.V., and Ryndina Yu.V, 'Stylistic Repetition In The Lyrics By Francis Albert Sinatra', Colloquium Journal, 8.60 (2020), 80-82 <https://doi.org/10.24411/2520- 6990-202011547>

Makinuddin, Mohammad, 'Mengebal Ushlub Dalam Struktur Kalimat Dan Makna', MIYAH, Jurnal Studi Islam, 14.2 (2018), 160-81

Malla, Agussalim Beddu, 'Nilai Estetika Al - Qur' an Dan Pengaruhnya Terhadap Jiwa', Tamaddun: Jurnal Bahasa, Sastra, Dan Budaya, 17.1 (2018), 4-6

Maskhuroh, Lailatul, 'Studi Pengulangan Ayat Pada Surat Al-Rahman (Telaah Atas Tafsir Al-Misbah)', Jurnal Unisda, 2018, 70-84 $<$ https://media.neliti.com/media/publications/265974-studipengulangan-ayat-pada-surat-al-rah-485246dc.pdf>

Mazur, Krystyna, Poetry and Repetition (Walt Whitman, Wallace Stevens, John Ashbery), ed. by William E. Cain (New York: Routledge Taylor \& Francis Group, 2005)

Mirshahi, Tahereh, and Ali Sabaghi, 'Repetition; the Stylistic Feature of Fakhr Al-Dīn Ibrahīm 'Irāqì's Lyrics', Iran Journals, 13.54 (2017), 143-62

Nailah, Rifatun, 'Penafsiran Ayat Tikrar Dalam Surah Al-Mursalat Menurut Muhammad 'Ali Al-Sabuni' (UIN Sunan Gunung Djati Bandung, 2018) 
Najib, Muhammad, and Muhammad Sayyidul Arwan, 'Ragam Makna Penafsiran Lafal Darran Dan Naf'an Secara Berdampingan (Kajian Pengulangan Al-Qur'an) Muhammad', ŚALIĤA, 3.1 (2020), 1-30

Nawas, A N M, M T Habeebullah, and A B M Aliyar, 'السجع في سورة القمر : در اسة ماسة 'تحليلية في علم البديع, in 6th International Symposium of FIA (Sri Lanka: South Eastern University of Sri Lanka, 2019), pp. 341-51

Nazri, Nurul Mukminah Zainan, Latifah Abdul Majid, and Wan Nasyrudin Wan Abdullah, 'Repetition of Al-Ma' and Ma' in Quranic Context: Meanings and Intents', Al-Turath Journal of Al-Quran and AlSunnah, 2.2 (2017), 80-87 <http://spaj.ukm.my/jalturath/index.php/jalturath/article/view /54>

Noviant, Hasmi, 'Penggunaan Majas Dalam Puisi Menggunakan Media Lagu Siswa Kelas VIII SMP Negeri I Gunung Talang', Jurnal $\begin{array}{llll}\text { Pendidikan Rokania, } & 2.2 \quad \text { (2017), } 200-209\end{array}$ <https://doi.org/10.1017/CB09781107415324.004>

Pamungkas, Sidiq Aji, and Kundharu Saddono, 'Repetisi Dan Fungsinya Dalam Novel Di Tanah Lada Karya Ziggy Zezsyazeoviennazabrizkie: Analisis Stilistika', METASASTRA: Jurnal Penelitian Sastra, 11.1 (2018), 113-30 <https://doi.org/10.26610/metasastra.2018.v11i1.113-130>

Pransiska, Toni, '(أسلوب التكرار في الأحاديث النبوية (دراسة تحليلية دلالية), Arabia: Jurnal Pendidikan Bahasa Arab, 10.1 (2018), 1-18

Qalyubi, Syihabuddin, Stilistika Bahasa Dan Sastra Arab (Yogyakarta: Karya Media, 2013)

Ratna, Nyoman Kutha, Stilistika: Kajian Puitika Bahasa, Sastra, Dan Budaya (Yogyakarta: Pustaka Pelajar, 2009)

Rohmatika, Alvyna, 'Repetisi Dalam Antologi Puisi Buku Latihan Tidur Karya Joko Pinurbo: Kajian Stilistika', Bapala, 5.2 (2018), 1-15

Safira, Fatimah, 'جمالية التكرار ودلالته في سورة الرحمن' (Mohamed Boudiaf University of M'Sila, 2017)

Salman, Sarhan Gafat, and Royam Abdulhasan Majhul, 'التكرار في خطاب 
'الاستكبار في القرآن الكريم (دراسة أسلوبية صوتية), Iraqi: Academic Scientific Journal, 18.4 (2018), 1-29

Septiani, Dwi, 'Majas Dan Citraan Dalam Puisi “Mishima” Karya Goenawan Mohamad (Kajian Stilistika)', Jurnal Sasindo Unpam, 8.1 (2020), $12-24$

Sugianto, Alip, 'Kajian Stilistika Terhadap Mantra Warok Etnik Jawa Panaragan', LEKSEMA: Jurnal Bahasa Dan Sastra, 1.2 (2016), 81$88<$ https://doi.org/10.22515/ljbs.v1i2.179>

Sukriyah, Siti, Sumarlam Sumarlam, and Djatmika Djatmika, 'Lexical Cohesion of Synonyms, Antonyms, and Repetitions on the Rubric of Children's, Adolescent's, and Adults' Story in the Daily Newspaper Kompas', Aksara, 30.2 (2018), 267-84 <https://doi.org/10.29255/aksara.v30i2.230.267-283>

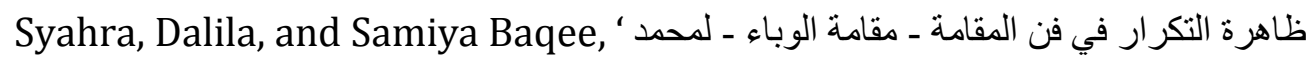
(Larbi Ben M’Hidi University, 2017)

Tarigan, Henry Guntur, Pengajaran Kosa Kata (Bandung: Angkasa, 1993)

Verhaar, J.W.M., Pengantar Linguistik (Yogyakarta: UGM Press, 1992)

Wahyu Hanafi, 'STILISTIKA AL-QUR'AN; (Ragam Gaya Bahasa Ayat-Ayat Țalab Dalam Diskursus Stilistika) Wahyu', Al Mabsut:Jurnal Studi Islam Dan Sosial, 11.1 (2017), 1-19

Wahyuni, Sri, and Mohd Harun, 'Analisis Struktur Fisik Dan Struktur Batin Poisi Anak Dalam Majalah Potret Anak Cerdas', Master Bahasa, 6.2 (2018), 115-23

Widodo, Wahyu, Mantra Kidung Jawa: Mengurai Yang Lingual Hingga Yang Transendental (Malang: UB Press, 2018)

Zahar, Erlina, 'Analisis Struktur Majas Seloko Hukum Adat Sebagai Bentuk Ekspresi Simbolik Nilai-Nilai Religius Masyarakat Melayu Jambi', Jurnal Ilmiah DIKDAYA, 8.1 (2018), 150-59 <https://doi.org/10.33087/dikdaya.v8i1.96> 